\title{
The Local Government Performance as Mediating Variable on the influence of Internal Control System on The Financial Statement Accountability: Evidence in Indonesia
}

\author{
Andy Dwi Bayu Bawono', Khadijah MD Arifin², Heppy Purbasari³, Andika Elis \\ Saputra $^{4}$ \\ \{andy.bawono@ums.ac.id¹,hadija@uthm.edu.my², heppy.purbasari@ums.ac.id³\} \\ Department of Accounting, Universitas Muhammadiyah Surakarta, Jl. Ahmad Yani, Tromol Pos I, \\ Pabelan, Surakarta, Jawa Tengah, Indonesia ${ }^{1,3,4}$ Department of Real Estate Management, Universiti Tun \\ Hussein Onn, 86400 Parit Raja, Johor, Malaysia²

\begin{abstract}
This study aims to examine the effect of local government internal control systems on the local financial statements accountability by using local governments' performance as the mediating variable. The internal control system was used as the dependent variable while financial report accountability was used as the independent variable. The population of this study consists of all local governments throughout Java Island, which financial statements had been published as at December 31, 2015 and audited by the Indonesian Government Supreme Auditor. This study adopted purposive sampling method as a way for selecting samples which resulted a total of 108 local governments involved. The multiple regression analysis was used for testing the data involved. The findings show that by using government's performance as the mediating variable resulted a more significant effect compared to the direct influence of internal control system to financial statement accountability.
\end{abstract}

Keywords: new public management, good governance, internal control system, local government performance, financial statement accountability, accrual accounting.

\section{Introduction}

Financial management reform in Indonesia has been growing relatively promising for more than two decades. The implementation of the New Public Management (NPM) concept within the scope of good governance is still being an appealing issue to campaign and further develop as a requirement of public on local government accountability [1]. The prominent of NPM was laying on how the government system should follow the private sector's approach in achieving effectiveness and efficiency [2], [3]. The development of the NPM and good governance concepts adopted from the application in several number of countries, especially Anglo Saxon countries, encourage the disclosure of public information including the financial report which contains several principals including disclosure, integrity, and accountability. Disclosure is needed to ensure that stakeholders have confidence in the decision-making and actions by the government institution. The disclosure atmosphere created through a comprehensive, accurate and effective communication process involving the stakeholders to ensure timely and effective implementation process of government activities [3], [4]. During the process in financial report preparation, the creation of integrity of organization's staff 
would be the guarantee for stakeholder which cannot be separated from the accountability of financial report as part of organization's financial performance.

In achieving good governance, an organization need to ensure the financial reporting process consist of several key factors such as internal control system, risk assessment, and systematic management process [5]. In the case of Indonesian local government, good governance is reflected from the government's performance report which are parallel to the implementation of accrual-based accounting to achieve financial accountability [6]. There are two performance reports imposed by the Indonesian Central Government to the local governments. The first report is called the Accountability Report of Government Agency Performance (LAKIP) which was developed by the Indonesian Ministry of State Apparatus Reform (MoSAR). The second report is called Local Government Performance Report (LPPD) which was developed by the Indonesian Ministry of Home Affairs (MoHA). Both reports will be submitted to the related ministry annually by the local government [7].

However, in the scope of public information, only the summary report of LPPD is presented to the public. This report aims to inform the implementation of the government's strategic plans and organizational functions in each local government department to the public. It also highlights the achievement of the government in improving the quality of future services.

In the 2010, for the requirement of better quality financial report, the Indonesian government issued the Government Regulation (GR) Number 71 in 2010 on Accrual Based Government Accounting Standard which revised the government accounting standard from cash toward accrual (CTA) to fully accrual based accounting [1], [4], [6]. This regulation ruled all level of government in Indonesia to reform their accounting basis to fully accrual based starting from 2015. In the first year of implementation, the Indonesian Supreme Auditor (BPK) revealed that the audited financial report of 542 local governments was given various opinions. Among others, four reports were given the adverse opinion (1\%), 31 reports were given the disclaimer opinion (5\%), 194 were given qualified opinion (36\%), and 313 were given unqualified opinion (58\%) [8]. This shows that the quality of financial reporting of local governments still needs improvement. The type of opinion given does influence the level of local government's financial statement accountability.

Study concerning an interaction of performance measurement, internal control system and local government accountability has been emerged in the public administration researches in several decades (see [4], [9], [10], [11], [12]). However, specific research on using internal control system as mediating variable in the interaction performance measurement in the financial statement accountability is limited. Therefore, the objective of this research is to examine the influence of the local government's internal control system toward the financial statement accountability by using local government's performance report as mediating variable. Internal control system refers to how management adequacy are designed and implemented, parallel to the standard and measurement of policies, guidelines and directions of the organization [13]. Thus, this research seeks to address the research questions as follows:

1. Is there any influence of internal control system to the local governments financial statement accountability in the first implementation of full accrual accounting bases in the Indonesian Local Government?

2. Is there any influence of internal control systems on accountability of financial statements by using the local governments' performance as mediating variable in the first implementation of full accrual accounting bases in the Indonesian Local Government? 
This research contribution lays on the originality of using the Indonesian local government performance report as mediating variable and elaborate the audit findings as a proxy of internal control variable.

\section{Literature Review}

In the recent public sector and politic research discourse, the notion "accountability" emerge and regularly interchangeably used with "good governance" [14], Accountability exist in portraying the government performance in the excellence level and well-mannered services but lower rate of expenses [15]. The World Bank (2007) argue that the adoption and implementation of accrual accounting system spread in the governments over the globe as part of financial management reform along with performance based budgeting system implementation [16]. Accrual accounting system has been inserted in this emphasis upon financial accountability, being the means that private sector mechanisms are introduced into public sector operations, concentrating the technical and economic at the part of the constitutional, legal and social [17]. Meanwhile, performance based budgeting aims to increase the transparency and accountability by providing information relating to an achievement of expected outcome from budget that will disburse in the next year [1]. Both of systems supported the government reform on its performance report and financial statements. These reports were significantly important for public accountability purpose through audit process by the government supreme auditor [4].

As part of the financial management reform, the huge demand of better performance measurement and performance information in supporting performance based budgeting were also rise in some developing countries and attempt to improve public accountability as well as performance and financial accountability [11], [18]. However, the low institutional capacity and high levels of corruption occurred, resulted for inadequate supply of performance information and data which further needed on the report of performance measurement and financial accountability [7]. In several cases, the function of accountability is to lower the information asymmetry between agent and principal to provide better information regarding the organization [19].

According to Aziz, et al. (2019), an enhancement of accountability in the public sector financial report need several factors which include internal control system, integrity system and leadership quality [10]. In more specific, the notion of good internal control mechanism is required to ensure and prevent an occurrence of poor financing as well as assist the operation of organization in achieving its efficiently and effectiveness [12].

In accordance with the theories previously expressed, researchers set the following hypotheses:

H1: The Internal Control System has an influence to the Local Government Performance

H2: The Local Government Performance has an influence on the Financial Statement Accountability

H3: The Internal Control System has an influence to the Financial Statement Accountability

H4: The Internal Control System has an influence on the Financial Statement Accountability through the Local Government Performance as mediating variable

This study utilizes quantitative methodology by using analysis of secondary data obtained from government report, website and regulations. The population in this study was 119 local governments which consists of city (kota) and districts (kabupaten) throughout the Java Island, 
Indonesia. The utilization of this Java Islands as a research object purposed to maintain the normality and homogeneity of data. Based on Rusmin, et al. (2014) suggestion, the local governments which located in the Java Island merely have similar pattern and financial condition portrayed in their financial statements. In Indonesia, Java Island is the most populated Island and has the better development on its cities and districts comparing to the other Islands [20]. Purposive sampling method was used to select the samples for this study. The criteria used for the sampling were determined based on the researcher's consideration that the local government:

a. Published its 2015 audited financial statements. The utilisation of this fiscal year financial statement is purposed to portray the financial circumstance during the first implementation of full accrual accounting in Indonesian local government as suggested by Prabowo, et al. [4].

b. Possessed consistent and complete data of the internal control system.

c. Published local performance report on the MoHA's website.

Based on the criteria above, a total of 108 local governments were selected as the samples of this study.

\subsection{Dependent Variable}

Financial statement accountability (FSA) was measured based on the status of opinions obtained from the BPK's audit report on the local government. The measurements scales included disclaimer opinions (scored 1), adverse opinions (scored 2), qualified opinion (scored 3 ), unqualified opinion with explanation language (scored 4), and unqualified opinion (scored 5) $[8]$.

\subsection{Independent Variable}

Based on the Committee of Sponsoring Organizations of the Treadway Commission (COSO), one of the internal control proponent was the audit findings, which shows efficiency and effectiveness of internal control in the organizations' management [21]. In Indonesia, the implementation of good internal control system within the government was imposed after an enactment of the Indonesian GR Number 60 in 2008 on the Government Internal Control System [18]. This regulation requires all level of Indonesian government to improve their internal control system. This system consists of 5 element of controls namely controlled environment, risk evaluation, controlled activity, information and communication, and monitoring internal control including the audit findings. The audit findings are presented in the frequency of the data or information that is significantly against the audit criteria [13]. The amount of audit findings of each local government on the financial statement's audit report are used as the proxy for the internal control system in this study.

\subsection{Mediating Variable}

The mediating variable used in this study was local government's performance rating based on the LPPD. This data was obtained from the published report through the appendix of MoHA Decree, number 120-10421 [25] on the 2015 of Ranking and Performance Status of Local Government Operations.

Measurement of this variable was based on the Indonesian GR Number 6/2008 on the Guidance of Local Government Accountability Evaluation which categories the local 
government ranking data as very high (5), high (4), moderate (3), low (2), and very low (1) [26].

The relation of each variable as a conceptual framework is depicted in Figure 1 below:

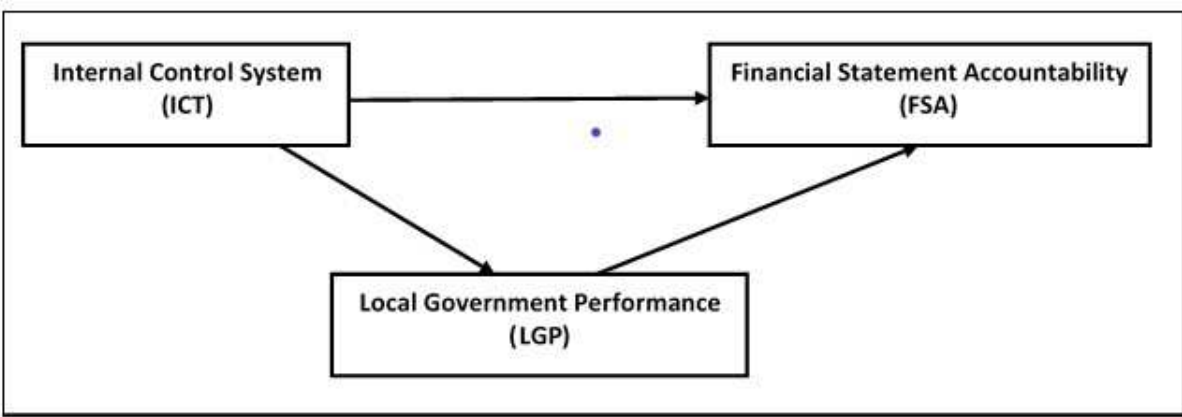

Fig.1. Conceptual Framework.

\subsection{Data Analysis}

This study used mediation analysis with ordinary least squares linear regression and path analysis for data analysis by using software IBM SPSS Statistics version 20.0. This method was used to analyse how much influence the independent variables have on the dependent variable. The regression equation model used to test the hypothesis is:

$$
\begin{aligned}
& \mathrm{Y}_{\mathrm{LGP}}=\mathrm{b}_{0}+\mathrm{b}_{\mathrm{ICT}} \mathrm{X}_{\mathrm{ICT}}+\mathrm{e}_{1} \ldots \ldots \ldots \ldots \ldots \ldots \ldots \ldots \ldots . . .2 \text { Regression equation } 1 \\
& \mathrm{Y}_{\mathrm{FSA}}=\mathrm{b}_{0}+\mathrm{b}_{\mathrm{ICT}} \mathrm{X}_{\mathrm{ICT}}+\mathrm{b}_{\mathrm{LCP}} \mathrm{X}_{\mathrm{LCP}}+\mathrm{e}_{2} \ldots \ldots . . \text { Regression equation } 2
\end{aligned}
$$

Where:

$\mathrm{Y}_{\mathrm{LGP}}=$ Local Government Performance

$\mathrm{X}_{\mathrm{ICT}}=$ Internal Control System

$\mathrm{Y}_{\text {FSA }}=$ Financial Statement Accountability

$\mathbf{b}_{\mathrm{LcT}}=$ Intercept of Internal Control System

$b_{\text {LGP }}=$ Intercept of Local Government Performance

$\mathrm{b}_{\mathrm{FSA}}=$ Intercept of Financial Statement Accountability

$\boldsymbol{e}_{1}=$ Residual of Local Government Performance

$e_{2}=$ Residual of Financial Statement Accountability

\section{Result And Discussion}

General problems in ordinal least square linear regression models were normality, multi collinearity, and heteroscedasticity. In this research, all the classical assumption tests have met with the requirement. Based on the linear regression analysis to determine the path analysis, the result of each analysis was shown in Table 1 below: 
Table 1. Path Analysis Summary

\begin{tabular}{llllll}
\hline Regression & $\begin{array}{l}\text { Unstandardized } \\
\text { Coefficient (Beta) }\end{array}$ & $\begin{array}{l}\text { Standardized } \\
\text { Coefficient (Beta) }\end{array}$ & t-value & $\begin{array}{l}\text { Sig } \\
(\mathrm{p} \text {-value) }\end{array}$ & Ref \\
\hline ICT $\rightarrow$ LGP & $-0,236$ & $-0,021$ & $-2,503$ & 0,014 & Significant \\
ICT $\rightarrow$ FSA & $-0,196$ & $-0,063$ & $-2,055$ & 0,042 & Significant \\
LGP $\rightarrow$ FSA & 0,202 & 0,744 & 2,122 & 0,036 & Significant \\
\hline
\end{tabular}

This study used mediation analysis with ordinary least squares linear regression and path analysis for data analysis by using software IBM SPSS Statistics version 20.0. This method was used to analyse how much influence the independent variables have on the dependent variable. The regression equation model used to test the hypothesis is:

\subsection{Internal Control System on Local Government Performance}

The test results of the t-value of the internal control system variable through the sum of audit finding showed a significant and negative influence on local government performance, with p-value $0.014<\alpha(0.05)$. This indicated that the better the internal control system with less findings resulted to the better the local government performance. This result was in line with the argument of Baltaci \& Yilmaz [22], stating that efficient and effective internal control system providing a reasonable assessment for government's performance. Furthermore, this finding also support the research of Badara \& Saidin [21], stating the closed correlation of performance measurement and internal control activities in order supporting the good governance.

\subsection{Local Government Performance on Financial Statement Accountability}

The results of the t-test showed that the Local Government Performance had a t-count of 2.122 with a significance value of 0.036 , smaller than the significance value of 0.05 . Therefore, it can be inferred that the local government performance significantly affected the financial statement accountability, meaning that the better the local government performance, the higher the possibility of the region to have high financial reporting accountability in the form of a good audit opinion. This finding was consistent with the previous researches stating that new financial reporting was relying from government performance measurement [23, 24]. Further, under the notion of NPM, the close relationship between public sector performance and accountability was also found in the public sector agency through the connections of providers (local government) and users in public services [19]. Moreover, this results were also supported by Kloot [27] study which found that an increasing of performance measurement provided substantial impact to the financial accountability in the government.

\subsection{Internal Control System on Financial Statement Accountability}

The test results showed that the internal control system through the sum of audit findings has a significant and negative effect on financial statement accountability, with a sign of 0.042 $<\alpha(0.05)$. The results indicated that the fewer the internal control system findings, the better the financial statement accountability. Based on the processed data, the local government had complied with the standards set by Law No. 60 of 2008 on the Government Internal Control System. In this regards, this finding confirm Baltaci \& Yilmaz [22], Rafindadi \& Olanrewaju [28], and Aikin [13] arguments that improvement of effective and efficient internal control system has a significant impact on the financial statement performance [26]. 


\subsection{Internal Control System influence on Financial Statement Accountability through Local Government Performance as Mediating Variable}

The effect of the direct coefficient can be analysed from the beta coefficients of each regression model. the direct effect of the internal control system on financial report accountability was $-0,196$. While the indirect effect can be calculated from the beta coefficient of SPI on KPD $\mathrm{x}$ beta coefficient of KPD on financial statement accountability, with the equation of $-0.236 \times 0.202=-0.0476$.

Therefore, the indirect effect $(-0.0476)$ was greater than the direct effect $(-0.196)$. In conclusion, the local government performance mediates the influence of the internal control system on financial statement accountability.

\section{Conclusions}

The results of the analysis and discussion of this study indicate several conclusions. First of all, in the first implementation of accrual accounting system in the Indonesian Local Government in 2015, an increasing internal control system made by the government through minimalizing the sum of audit finding in the audit report will improve the performance of local government portrayed in the score and rank of LPPD published by MoHA. Second of all, the good score of local government performance portrayed in its LPPD rank has a significant effect on increasing the financial statement accountability through the opinion of local government statement made by Indonesia Supreme Auditor. Furthermore, the increasing of internal control system has a significant influence on local government financial statement accountability portrayed on the opinion given by the auditor. Finally, the internal control system indirectly influences the financial statement accountability through the local government performance as the mediating variable. Thus, the increasing the internal control system that was showed from minimalizing audit finding would be impacted to the better performance in local government and continuously improved the accountability of local government through the audit opinion of their financial statements.

There are several suggestions made based on the conclusions and limitations of the study. Further researches should expand the objects of research such as in entire Indonesia, therefore the results of research are able to represent the area simultaneously. Moreover, future research is expected to use data after several years of implementation to examine is whether the results changes. Also, several variables such as administrative reform, the local government size and other forms of accountability such as political, administrative, and managerial accountability could be added as an independent or mediating variable.

\section{References}

[1] Bawono, A. D. B.: The Role of Performance Based Budgeting in the Indonesian Public Sector. Ph.D Thesis, Australia: Macquarie University (2015)

[2] Guthrie, H. C., Jones, L. R. \& Orson, O.: International Public Financial Reform: progress, contradictions, and the challenges. United States of America, Information Age Publishing Inc (2005) 
[3] Pollitt, C. \& Bouckaert, G.: Public Management Reform. A Comparative Analysis: New Public Management, Governance, and The Neo-Weberian State, New York, Oxford University Press (2011)

[4] Prabowo, TJW, P. Leung, J. Guthrie.: Reforms in Public Sector Accounting and Budgeting in Indonesia (2003-2015): Confusions in Implementation, Journal of Public Budgeting, Accounting \& Financial Management, 29 (1), pp. 104-137 [2017]

[5] Leung, Philomena, Cooper, Barry J. and Perera, Luckmika.: Accountability structures and management relationships of internal audit: An Australian study. Managerial Auditing Journal, 2 (9), pp. 794-816 [2011]

[6] Harun, H., Van Peursem, K. \& Eggleton, I.: Institutionalization of Accrual Accounting in the Indonesian Public Sector. Journal of Accounting \& Organizational Change, 8, pp. 257-285 (2012)

[7] Mimba, N. P. S., Helden, G. J. \& Tillema, S.: The Design and Use of Performance Information in Indonesian Local Governments Under Diverging Stakeholder Pressures. Public Administration and Development, 33, pp. 15-28 (2013)

[8] Indonesian Supreme Auditor (Badan Pemeriksa Keuangan Republik Indonesia).: Local Government Financial Report Audit (Laporan Hasil Pemeriksaan Laporan Keuangan Pemerintah Daerah). Jakarta. (2016)

[9] Mimba, N. P. S., Helden, G. J. \& Tillema, S.: Public Sector Performance Measurement in Developing Countries: A Literature Review and Research Agenda. Journal of Accounting and Organizational Change, Vol 3. No. 3, pp. 192-208 (2007)

[10] Aziz, M. A. A., Rahman, H. A., Alam, M. M., \& Said, J.: Enhancement of the Accountability of Public Sectors through Integrity System, Internal Control System and Leadership Practices: A Review Study. Procedia Economics and Finance, 28, 163-169 (2015)

[11] Price, A., Schwartz, R., Cohen, J., Scott, F., \& Manson, H., 2016. Pursuing performance and maintaining compliance: Balancing performance improvement and accountability in Ontario's public health system. Canadian Public Administration, 59(2) (2016).

[12] Wardiwiyono, S.: Internal control system for Islamic Micro Financing: An Exploratory Study of Baitul Maal wat Tamwil in the City of Yogyakarta Indonesia. International Journal of Islamic and Middle Eastern Finance and Management, 5(4), 340-352 (2012)

[13] Aikins, Stephen Kwamena.: An Examination of Government Internal Audits' Role in Improving Financial Performance. Public Finance and Management, 11 (4), pp 306-337 (2011)

[14] Boven, Mark.:Analysing and Assessing Public Accountability. A Conceptual Framework. European Governance Paper (EUROGOV) No. C-06-01 (2006)

[15] O'Connel, L.: Program Accountability as an Emergent Property: The Role of Stakeholder in Program's Field., Public Administration Review, 65 (1) pp 85-93 (2005)

[16] The World Bank.: Report on the Observance of Standards and Codes (ROSC). Accounting and Auditing Report No. AAA35-AR Argentina (2007)

[17] Gray, Andrew, and Bill Jenkins.: Codes of accountability and in the new public sector. Accounting, Auditing, and Accountability Journal, 6 (3): 52-67 (1993)

[18] Mimba, N. P. S.: Public Sector Performance Measurement in Less Developed Country. Ph.D Thesis, The Netherlands: University of Groningen (2011)

[19] Christensen, T \& Laegreid P.: Performance and Accountability -A Theoretical Discussion and an Empirical Assessment. Public Organization Review, 15, pp 207-225 (2015)

[20] Rusmin, Rusmin; Astami, Emita W.; and Scully, Glennda.: Local Government Units in Indonesia: Demographic Attributes and Differences in Financial Condition, Australasian Accounting, Business and Finance Journal, 8(2), 2014, 88-109 (2014)

[21] Badara, Saidu, M. \& Zaidin S. Z.: Impact of the Effective Internal Control System on the Internal Audit Effectiveness at Local Government Level, Journal of Social and Development Sciences, 4 (1), pp. 16-23 (2013)

[22] Baltaci, Mustafa \& Serdar Yilmaz.: Keeping an Eye on Subnational Governments: Internal Control and Audit at Local Levels. The World Bank Institute, Washington DC (2006) 
[23] Mead, D. M.: A Manageable System of Economic Condition Analysis for Governments. In H. Frank (Ed.), Public Financial Management, pp. 383 - 419. Boca Raton, FL: Taylor \& Francis (2006)

[24] Rivenbark, William C., D. J. Roenigk, G. S. A.: Conceptualizing Financial Condition In Local Government, Journal of Public Budgeting, Accounting \& Financial Management, 22 (2), pp. 149-177 (2010)

[25] Indonesian Ministry of Home Affair (MoHA).: MoHA Decree number 120-10421 on the 2015 of Ranking and Performance Status of Local Government Operations. Indonesian Government. Jakarta. (2016)

[26] Indonesian Government.: Indonesian Government Regulation Number 6 in 2008 on the Guidance of Local Government Accountability Evaluation. Indonesian Government. Jakarta. (2008)

[27] Kloot, L.: Performance Measurement and Accountability in Victorian Local Government, International Journal of Public Sector Management, Vol. 12 No. 7, pp. 565-584 (1999)

[28] Rafindadi, A. A., \& Olanrewaju, Z. A.: The Impact of Internal Control System on The Financial Accountability of Non-Governmental Organisations in Nigeria: Evidence from the Structural Equation Modelling. International Review of Management and Marketing, 9(3), 49-63. (2019) 